\title{
Investigation of feasibility and Risk in BOT Road project
}

\author{
Ganesh R Nile \\ Department of civil engineering and construction management engineering \\ SSGB collage of engg and technology, Bhusavwal, Maharashtra, India \\ Prof.P M Attarde \\ Department of civil engineering and construction management engineering \\ SSGB collage of engg and technology, Bhusavwal, Maharashtra, India
}

\begin{abstract}
A project is financially viable for the private entity if the revenues generated by the project cover its cost and provide sufficient return on investment. The viability of the project for the host government depends on its efficiency in comparison with the economics of financing the project with public funds. The private sector operates project long enough to payback project debt and equity investment. Before investment, the feasibility of the project has to be done that gives figures of cash flow on the following years. This study involves feasibility study and risk involved in particular case of Nashik-Pune National Highway No.50 from kms. 177/000 to kms.201/310 [Nashik-Sinner] Total 25.31 kms
\end{abstract}

Keywords - Feasibility, Fund, Risk,, Debt, Equity, Payback period

\section{INTRODUCTION}

Feasibility report is prepared during the initial phase or definition phase of the project updating and validation of the feasibility report is required for implementation of the project. The project can be implemented as per techno economic stipulation made in the feasibility report. A feasibility report is prepared to present an in depth techno economic analysis carried out on the project and contain result of technical as well as economic evaluation of the project so that the owner can take investment decision and project can be properly planned and implemented.

The viability of any project mainly depends on the Technical analysis, Financial analysis, Economic analysis, Risk analysis Hence it can very well understood that feasibility study is the base for success of a project and major part of this success lies in proper technical economical and financial analysis.

For a construction project, it is very important to take into consideration that various risk involved in the project at various stages while assessing the technical, economical and financial Feasibility of the project. The risks vary widely from sector to sector, project to project and stages to stages and it is to be identified by means of suitable qualitative technique. The potential impact and their probability of occurrence are to be evaluated and risk management has to be done accordingly. Thus it is very important that detailed work should be done to identify means of risk management while detailing out the technical, economical and financial analysis and hence formed the base for the project work.

Construction companies and firms, such as the government, consultants and contractors, normally face different kinds of risks during construction. Risk identification is the first process in risk management. Risk identification is important to know how the players in the construction industry handle risk identification. Without having any perspective on or approach for risk identification, construction participants cannot make appropriate decisions in other risk management processes.

Risk is inherent in every business decision. Risks have a major influence on the success or failure of a project. They must be managed by applying a conscientious effort to their reduction or elimination. Not all risks need to be eliminated entirely; often it is sufficient to reduce the project's exposure to a level that is acceptable to the project.

\section{DATA COLLECTION}

Project Background : Ministry of Road Transport and Highways has decided to undertake the development of various National Highway stretches where traffic intensity has increased significantly and there is an urgent need of augmentation of capacity for safe and efficient movement of traffic. The development of these stretches are 
proposed through Public Works Departments of various states as executing agency. Accordingly the stretch from Km. 177/000 to Km. 208/650 part of Pune -Nashik - NH 50 near Nashik City including Sinnar Bypass is chosen for implementation on BOT basis.

Means of Finance

\begin{tabular}{|c|c|}
\hline MEANS OF FINANCE & AMOUNT(RS.CR) \\
\hline Government Grant & 120 \\
\hline Equity/Quasi equity & 59.1 \\
\hline Debt & 137.9 \\
\hline Total Project Cost & 317.304 \\
\hline
\end{tabular}

Input data for financial analysis

\begin{tabular}{|c|c|}
\hline Physical Contingency Charges & $3 \%$ \\
\hline Construction Cost Phasing : Yr. 2015-2016 & $40 \%-60 \%$ \\
\hline Escalation in Cost & $5 \%$ \\
\hline Interest During Construction (IDC) & $12 \%$ \\
\hline Grant & 0.13 Million INR/Km/Yr) \\
\hline General Maintenance Cost & 0.60 Million INR/Km/ $/ 5^{\text {th }}$ Yr) \\
\hline Periodic Maintenance Cost & $6.0($ MillionINR/Yr/Toll Plaza) \\
\hline Total Administrative Cost & 15 Years \\
\hline Loan Repayment Period & $36.6 \%$ \\
\hline Tax Liability & $3 \%$ \\
\hline
\end{tabular}

\section{ANALYSIS AND RESULS}

1. Average Rate of Return (ARR) The rate of return on an investment that is calculated by taking the total cash inflow over the life of the investment and dividing it by the number of years in the life of the investment. The average rate of return does not guarantee that the cash inflows are the same in a given year; it simply guarantees that the return averages out to the average rate of return

2. Payback Period (PBP) In project evaluation and capital budgeting, the payback period estimates the time required to recover the principal amount of an investment. $\hat{A}$ Because the payback period method ignores any benefits that occur after the investment is repaid and the time value of money, other methods of investment analysis are often preferred.

3. Net Present value (NPV) The discounted value of an investment's cash inflows minus the discounted value of its cash outflows. To be adequately profitable, an investment should have a net present value greater than zero. For investment in securities, the initial cost is usually the only outflow. 
1. Net present value

\begin{tabular}{|c|c|c|c|c|}
\hline Year & Particulars & $\begin{array}{c}\text { Cash } \\
\text { Flow } \\
\text { (Rs. In } \\
\text { Crs) }\end{array}$ & $\begin{array}{c}\text { Discounting } \\
\text { Factor @ } \\
\mathbf{1 2 \%}\end{array}$ & $\begin{array}{c}\text { Discounted } \\
\text { Cash Flow } \\
\text { (Rs. In Crs) }\end{array}$ \\
\hline 2016 & Cost of Project & -126.92 & 1.00 & -126.92 \\
\hline 2016 & Grant & 48.00 & 1.00 & 48.00 \\
\hline 2016 & Borrowings & 138.00 & 1.00 & 138.00 \\
\hline 2017 & Cost of Project & -190.38 & 0.89 & -169.98 \\
\hline 2017 & Grant & 72.00 & 0.89 & 64.29 \\
\hline 2018 & Cash Flow & -1.52 & 0.80 & -1.21 \\
\hline 2019 & Cash Flow & 0.64 & 0.71 & 0.46 \\
\hline 2020 & Cash Flow & 3.03 & 0.64 & 1.93 \\
\hline 2021 & Cash Flow & 5.66 & 0.57 & 3.21 \\
\hline 2022 & Cash Flow & 7.60 & 0.51 & 3.85 \\
\hline 2023 & Cash Flow & 11.77 & 0.45 & 5.32 \\
\hline 2024 & Cash Flow & 15.30 & 0.40 & 6.18 \\
\hline 2025 & Cash Flow & 19.20 & 0.36 & 6.92 \\
\hline 2026 & Cash Flow & 23.50 & 0.32 & 7.57 \\
\hline 2027 & Cash Flow & 28.23 & 0.29 & 8.12 \\
\hline 2028 & Cash Flow & 33.47 & 0.26 & 8.59 \\
\hline 2029 & Cash Flow & 39.22 & 0.23 & 8.99 \\
\hline 2030 & Cash Flow & 45.57 & 0.20 & 9.32 \\
\hline 2031 & Cash Flow & 52.57 & 0.18 & 9.61 \\
\hline 2032 & Cash Flow & 59.56 & 0.16 & 9.71 \\
\hline 2033 & Cash Flow & 88.88 & 0.15 & 12.94 \\
\hline 2034 & Cash Flow & 99.12 & 0.13 & 12.89 \\
\hline & NET NPV & & & $\mathbf{5 4 . 8 9}$ \\
\hline
\end{tabular}

From cash flow it is also observe that Payback Period $=10$ years

2. Profitablility statement

\begin{tabular}{|r|r|r|r|r|r|r|r|r|r|r|r|r|}
\hline $\begin{array}{r}\text { Sr. } \\
\text { No }\end{array}$ & Year & $\begin{array}{c}\text { Toll } \\
\text { Revenue }\end{array}$ & $\begin{array}{c}\text { Gen } \\
\text { Mainten } \\
\text { nce } \\
\text { Charges }\end{array}$ & $\begin{array}{c}\text { Admi } \\
\text { nistra } \\
\text { tion } \\
\text { Charg } \\
\text { es }\end{array}$ & $\begin{array}{c}\text { Periodic } \\
\text { Mainte } \\
\text { nance } \\
\text { Charges }\end{array}$ & $\begin{array}{c}\text { Toll } \\
\text { Charg } \\
\text { es }\end{array}$ & $\begin{array}{c}\text { Intere } \\
\text { st }\end{array}$ & $\begin{array}{c}\text { Profit } \\
\text { Before } \\
\text { Tax }\end{array}$ & Tax & EMI & $\begin{array}{c}\text { Cash } \\
\text { Flow }\end{array}$ & PAT \\
\hline 1 & 2018 & 36.92 & 0.33 & 15.19 & 0.00 & 1.50 & 16.56 & 3.34 & 1.22 & 20.2 & -1.52 & 2.12 \\
\hline 2 & 2019 & 40.71 & 0.33 & 15.24 & 0.00 & 1.58 & 16.12 & 7.44 & 2.72 & 20.2 & 0.64 & 4.72 \\
\hline 3 & 2020 & 44.88 & 0.33 & 15.29 & 0.00 & 1.65 & 15.63 & 11.98 & 4.39 & 20.2 & 3.03 & 7.60 \\
\hline 4 & 2021 & 49.48 & 0.33 & 15.34 & 0.00 & 1.74 & 15.09 & 16.99 & 6.22 & 20.2 & 5.66 & 10.77 \\
\hline 5 & 2022 & 54.55 & 0.33 & 15.39 & 1.52 & 1.82 & 14.47 & 21.02 & 7.69 & 20.2 & 7.60 & 13.33 \\
\hline 6 & 2023 & 60.15 & 0.33 & 15.44 & 0.00 & 1.92 & 13.79 & 28.68 & 10.50 & 20.2 & 11.77 & 18.18 \\
\hline 7 & 2024 & 66.31 & 0.33 & 15.49 & 0.00 & 2.01 & 13.02 & 35.47 & 12.98 & 20.2 & 15.30 & 22.49 \\
\hline 8 & 2025 & 73.10 & 0.33 & 15.54 & 0.00 & 2.11 & 12.15 & 42.97 & 15.73 & 20.2 & 19.20 & 27.24 \\
\hline 9 & 2026 & 80.60 & 0.33 & 15.59 & 0.00 & 2.22 & 11.19 & 51.28 & 18.77 & 20.2 & 23.50 & 32.51 \\
\hline 10 & 2027 & 88.85 & 0.33 & 15.64 & 0.00 & 2.33 & 10.11 & 60.45 & 22.12 & 20.2 & 28.23 & 38.32 \\
\hline
\end{tabular}




\begin{tabular}{|r|r|r|r|r|r|r|r|r|r|r|r|r|}
\hline 11 & 2028 & 97.98 & 0.33 & 15.69 & 0.00 & 2.45 & 8.89 & 70.62 & 25.85 & 20.2 & 33.47 & 44.77 \\
\hline 12 & 2029 & 108.00 & 0.33 & 15.74 & 0.00 & 2.57 & 7.54 & 81.83 & 29.95 & 20.2 & 39.22 & 51.88 \\
\hline 13 & 2030 & 119.08 & 0.33 & 15.79 & 0.00 & 2.70 & 6.02 & 94.25 & 34.49 & 20.2 & 45.57 & 59.75 \\
\hline 14 & 2031 & 131.29 & 0.33 & 15.84 & 0.00 & 2.83 & 4.32 & 107.98 & 39.52 & 20.2 & 52.57 & 68.46 \\
\hline 15 & 2032 & 144.75 & 0.33 & 15.89 & 0.00 & 2.80 & 0.11 & 125.62 & 45.98 & 20.2 & 59.56 & 79.65 \\
\hline 16 & 2033 & 159.57 & 0.33 & 15.94 & 0.00 & 3.12 & 0.00 & 140.18 & 51.31 & 0.00 & 88.88 & 88.88 \\
\hline 17 & 2034 & 175.94 & 0.33 & 15.99 & 0.00 & 3.28 & 0.00 & 156.34 & 57.22 & 0.00 & 99.12 & 99.12 \\
\hline 18 & 2035 & 193.98 & 0.33 & 16.04 & 0.00 & 3.44 & 0.00 & 174.17 & 63.75 & 0.00 & 110.43 & 110.43 \\
\hline 19 & 2036 & 213.86 & 0.33 & 16.09 & 0.00 & 3.62 & 0.00 & 193.82 & 70.94 & 0.00 & 122.89 & 122.89 \\
\hline 20 & 2037 & 235.77 & 0.33 & 16.14 & 0.00 & 3.80 & 0.00 & 215.50 & 78.87 & 0.00 & 136.63 & 136.63 \\
\hline 21 & 2038 & 259.94 & 0.33 & 16.19 & 0.00 & 3.99 & 0.00 & 239.43 & 87.63 & 0.00 & 151.80 & 151.80 \\
\hline 22 & 2039 & 286.60 & 0.33 & 16.24 & 0.00 & 4.18 & 0.00 & 265.85 & 97.30 & 0.00 & 168.55 & 168.55 \\
\hline 23 & 2040 & 315.96 & 0.33 & 16.29 & 0.00 & 4.40 & 0.00 & 294.94 & 107.95 & 0.00 & 187.00 & 187.00 \\
\hline 24 & 2041 & 348.35 & 0.33 & 16.34 & 0.00 & 4.62 & 0.00 & 327.06 & 119.71 & 0.00 & 207.36 & 207.36 \\
\hline 25 & 2042 & 384.06 & 0.33 & 16.39 & 0.00 & 4.85 & 0.00 & 362.49 & 132.67 & 0.00 & 229.82 & 229.82 \\
\hline
\end{tabular}

3. Average rate of return

\begin{tabular}{|c|c|c|c|}
\hline Year & Net Inflow & Net Outflow & Profit \\
\hline 2018 & -1.52 & 11.65 & -13.17 \\
\hline 2019 & 0.64 & 11.65 & -11.01 \\
\hline 2020 & 3.03 & 11.65 & -8.62 \\
\hline 2021 & 5.66 & 11.65 & -5.99 \\
\hline 2022 & 7.60 & 11.65 & -4.05 \\
\hline 2023 & 11.77 & 11.65 & 0.12 \\
\hline 2024 & 15.30 & 11.65 & 3.65 \\
\hline 2025 & 19.20 & 11.65 & 7.55 \\
\hline 2026 & 23.50 & 11.65 & 11.85 \\
\hline 2027 & 28.23 & 11.65 & 16.58 \\
\hline 2028 & 33.47 & 11.65 & 21.82 \\
\hline 2029 & 39.22 & 11.65 & 27.57 \\
\hline 2030 & 45.57 & 11.65 & 33.92 \\
\hline 2031 & 52.57 & 11.65 & 40.92 \\
\hline 2032 & 59.56 & 11.65 & 47.91 \\
\hline 2033 & 88.88 & 11.65 & 77.23 \\
\hline 2034 & 99.12 & 11.65 & 87.47 \\
\hline Total & 531.79 & 198.05 & 19.63 \\
\hline
\end{tabular}


$\mathrm{ARR}=$ Average profit/Total investment

$=19.63 / 198.05=9.91 \%$

Risks identified in the Project under study

1. Demand risk :- It was told that the villagers of Mangaon have stopped the work of around $60 \mathrm{~m}$ length with the demand of pedestrian underpass and vehicular underpass.

Effect- Delay in construction due to stop of work and .Major effect on change of scope

Metigation-From study it is suggested that at mangaon village as per demand of villagers the pedestrian underpass and vehiculal underpass is necessary to constructed to save time and money of users this also save fuel and automatically this should help in economic development of country. From due to change of scope of work the unnecessary cost of project increases and the compensation for this cost should be awarded to contractor.

2. Land dispute :-Near shindegaon $7 \mathrm{~km}$ from nasik land acquisition problem create an dispute.

Effect- Political issues create more problem, Irritation to both parties involve in BOT and Disputal environment create it reduces work efficiency

Metigation-To Solve land acquisition project enough compensation to farmers for that land.should be given, Handle situation with peace mind to avoid unwilling working conditions

\section{IV.CONCLUSION}

1. The application of Biult Operate And Transfer (BOT) has become increasingly important in the development and delivery of public projects

2. The Concession period of project is 19 years wih the Net Present Value of the project comes to 54.89 crores which is positive. So the project falls under acceptance criteria for investment. The payback period of the project is 10 years The Average Rate Of Return “(ARR) OF Project is $9.91 \%$

3. The Nashik city is very near to project stretch as also Sinnar town. Also Sinnar MIDC \& other private industrial area is adjoining to project stretch, Due to existence of many villages along the road length and availability of skilled and unskilled workers will not be a problem. Therefore this project is viable on the basis of commercial consideration as well as its engineering feasibility

4. Every risk directly or indirectly impacts the financial feasibility. The financial viability of the proposed project depends on the debt servicing and the expected return of the project.

\section{REFERENCES}

[1] Esther Malini, "Built Operate and Transfer Municipal Bridge Projects in India", journal of management in engineering, year 1999,page no $51-58$

[2] RinajPathan, S.S. Pimplikar "Case Study of Tolled Road Project",IOSR Journal of Mechanical and Civil Engineering (IOSR-JMCE), Volume 7 -ISSN: 2278-1684,p-ISSN: 2320-334X, , Issue 6 (Jul. - Aug. 2013), PP 26-32

[3] Vanashree Vanarase, Economic and Financial Analysis for Feasibility Study of Public Private Partnership Road Project, International Journal on Recent and Innovation Trends in Computing and Communication, Volume: 4 Issue4 : ISSN: 2321-8169, April 2016, page no $182-185$

[4] R. R. Kshatriya, M. B. Murkute, Financial sensitivity analysis and comparison between moderate and extreme condition International Conference on Explorations and Innovations in Engineering \& Technology, ISSN: 2348 - 8352, year 2016 Page 1-5

[5] A.P.WAGHMARE, Dr. S.S.PIMPLIKAR, Risk Analysis In Feasibility Study Of Road Construction Project: Case Study Construction Of The Four Laning Of Amravati -Talegaon Section Nh-6., International Journal of Engineering Research and Applications (IJERA) ISSN: 2248-9622 Vol. 2, Issue 3, May-Jun 2012, page no 3166-3169 3166

[6] Yadav Ashwini Ashok, B.V.Birajdar, Risk analysis and management for public-private partnership infrastructure projects in india, International Research Journal of Engineering and Technology (IRJET) e-ISSN: 2395 -0056 ISSN: 2395-0072 Volume: 02 Issue: 04,July2015 - Page 1549-1551

[7] Kitti subprasom Anthony chen (2005) "Analyasis of policy and regulation on BOT scheme,A case study of the ban pong kanchanburi motorway in thailand "Journal of the Eastern Asia Society for Transportation Studies, Vol. 6, pp. 3883 - 3898 , 